\title{
Author Correction: Discovery of widespread transcription initiation at microsatellites predictable by sequence-based deep neural network
}

\author{
Mathys Grapotte, Manu Saraswat, Chloé Bessière, Christophe Menichelli (D, Jordan A. Ramilowski(D, \\ Jessica Severin (10, Yoshihide Hayashizaki (1), Masayoshi Itoh (1), Michihira Tagami, Mitsuyoshi Murata, \\ Miki Kojima-Ishiyama, Shohei Noma, Shuhei Noguchi, Takeya Kasukawa (1D, Akira Hasegawa, \\ Harukazu Suzuki D, Hiromi Nishiyori-Sueki, Martin C. Frith, FANTOM consortium*, \\ Clément Chatelain, Piero Carninci (1), Michiel J. L. de Hoon (1), Wyeth W. Wasserman (1), \\ Laurent Bréhélin (iD) \& Charles-Henri Lecellier (D)
}

Correction to: Nature Communications https://doi.org/10.1038/s41467-021-23143-7, published online 2 June 2021.

The original version of this Article incorrectly included Kristina Hettne as a current member of the FANTOM consortium at the time of publication. This has now been corrected in both the PDF and HTML versions of the Article.

Published online: 01 March 2022

\begin{abstract}
(c) (i) Open Access This article is licensed under a Creative Commons Attribution 4.0 International License, which permits use, sharing, adaptation, distribution and reproduction in any medium or format, as long as you give appropriate credit to the original author(s) and the source, provide a link to the Creative Commons license, and indicate if changes were made. The images or other third party material in this article are included in the article's Creative Commons license, unless indicated otherwise in a credit line to the material. If material is not included in the article's Creative Commons license and your intended use is not permitted by statutory regulation or exceeds the permitted use, you will need to obtain permission directly from the copyright holder. To view a copy of this license, visit http://creativecommons.org/licenses/by/4.0/.
\end{abstract}

(C) The Author(s) 2022, corrected publication 2022 